\title{
MENGEMBANGKAN KARAKTER MENGHARGAI PERBEDAAN MELALUI PENDIDIKAN MULTIKULTURAL
}

\author{
Murniati Agustian, Pricilla Anindyta, Maria Grace
}

Fakultas Pendidikan dan Bahasa Universitas Atmajaya

pricilla.anindyta@atmajaya.ac.id, mariagracelendo30@gmail.com

\begin{abstract}
ABSTRAK
Pengabdian masyarakat ini bertujuan untuk menyadarkan warga sekolah (guru dan siswa) SD Fransiskus Lampung bahwa pendidikan multikutural penting untuk diimplementasikan dan dapat mengembangkan karakter yang menghargai perbedaan. Lampung menjadi tempat pengabdian karena konflik antar suku sudah beberapa kali terjadi. Metode pelaksanaannya adalah melakukan survey awal ke SD Fransiskus Lampung untuk melakukan analisis kebutuhan. Berdasarkan hasil analisis kebutuhan, dirancang kegiatan yaitu seminar dengan guru-guru SD dan kegiatan mengajar di kelas oleh mahasiswa secara berkelompok. Mahasiswa didampingi membuat rancangan pembelajaran dengan berbagai permainan dengan mengaplikasikan teori yang mereka pelajari dari mata kuliah pendidikan multikultural dan pendidikan karakter. Hasil akhir dari kegiatan pengabdian masyarakat ini adalah, guru-guru mempunyai gambaran tentang pelaksanaan pendidikan multikultural di kelas. Pendidikan multikultural dimaknai sebagai pendekatan dalam kegiatan pembelajaran dimana siswa yang beragam disatukan dengan berbagai permainan. Artinya siswa mengalami bukan hanya diceramahi. Topik ini merupakan pengetahuan baru bagi guru dan guru merasakan manfaat pentingnya materi yang diberikan khususnya dengan melihat situasi wilayah mereka yang beberapa tahun terakhir ini terjadi konflik antarbudaya. Siswa juga merasakan bahwa belajar dengan mahasiswa sangat menyenangkan bagi mereka. Melalui kegiatan ini, disarankan agar pendidikan multikultural yang dapat mengembangkan karakter menghargai perbedaan dapat terintegrasi dengan kegiatan belajar siswa SD.

Kata kunci: pendidikan multikultural, pendidikan karakter, karakter menghargai perbedaan.
\end{abstract}

\section{PENDAHULUAN}

Sikap menghargai perbedaan sangat penting dikembangkan pada anak-anak di Indonesia karena Indonesia merupakan salah satu negara yang sangat beragam. Dengan jumlah penduduk Indonesia 261,1 juta (2016), terdapat 633 kelompok suku besar, hasil klasifikasi Badan Pusat Statistik (BPS) bekerjasama dengan Institute of Southeast Asia Studies pada tahun 2013. Data BPS 2010, suku Jawa yang berasal dari Pulau Jawa merupakan kelompok suku bangsa yang terbesar dengan populasi sebanyak 95,2 juta jiwa atau sekitar 40,2 persen dari populasi penduduk Indonesia. Suku bangsa terbesar berikutnya secara berturut-turut adalah Suku Sunda dengan jumlah sebanyak 36,7 juta jiwa (15,5 persen), Suku Batak sebanyak 8,5 juta (3,6 persen) dan Suku asal Sulawesi (tidak termasuk Suku Makassar, Bugis, Minahasa dan Gorontalo) sebanyak 7,6 juta jiwa (3,2 persen). Indonesia memiliki 748 bahasa ibu dari 67 bahasa induk yang digunakan berbagai suku bangsa, 79,5 persen dari seluruh populasi penduduk usia 5 tahun ke atas melakukan komunikasi sehari-hari di rumah tangga dengan menggunakan bahasa daerah. Selain memiliki suku yang beragam, masyarakat Indonesia menganut enam agama yang diakui oleh pemerintah yaitu Islam $(87,18 \%)$, Kristen (6,96\%), Katolik (2,91\%), Hindu (1,69\%), Budha (0,72), dan Khonghucu (0,05\%), sementara sebagian masyarakat masih ada yang menganut keyakinan lain. Banyaknya suku di Indonesia memunculkan budaya yang beragam pula.

Keberagaman budaya dan agama sangatlah indah dan menakjubkan sehingga sering dikatakan bagai ratna mutu manikam, di sisi lain keberagaman juga potensial terjadinya konflik bila tidak diantisipasi sebelumnya. Fisher dkk (2000), mengatakan budaya menentukan cara seseorang bertindak, budaya menentukan perilaku seseorang dalam berhubungan dengan orang lain dan bahkan cara seseorang berpikir dan memahami sesuatu yang terjadi di sekitarnya, ditentukan oleh budaya. Konflik yang terjadi di Indonesia seperti yang tergambar dalam beberapa pemberitaan belakangan ini sangat 
mengkhawatirkan.

Hapsin, dkk (2016) mengatakan aspek yang dapat memicu konflik beragama sangat banyak, yakni meliputi adanya prasangka (prejudice), seperti adanya kecurigaan masing-masing akan kejujuran pihak lain, baik intern umat beragama maupun antar umat beragama; perbedaan agama; sifat dari masing-masing agama yang mengandung tugas dakwah atau missi; kompetisi ekonomi; perbedaan etnik; cara pandang literalisme seperti pemahaman radikal atau yang menganggap hanya aliran/mazhabnya sendiri yang benar dan menyalahkan yang lain; kurangnya pengetahuan para pemeluk agama akan agamanya sendiri dan agama lain, sehingga mudah diombang-ambingkan oleh isu yang berkembang.

Konflik agama yang terjadi dapat dengan jelas diamati seperti yang diberitakan beberapa media yaitu: Jakarta, CNN Indonesia - "Penyerangan terhadap kegiatan ibadah di Gereja St. Lidwina, Sleman, DIY, Minggu (12/2) dianggap, sebagai bentuk kepercayaan diri yang samakin tinggi dari kelompok intoleran. Ketegasan pihak kepolisian akan jadi kunci untuk memukul balik gerakan ini”. BBC Indonesia- "Kepolisian Daerah Papua diminta segera menuntaskan penyelidikan insiden pembakaran kios dan musala serta pembubaran salat Idul Fitri di Tolikara, Papua, Jumat (17/07) lalu, sehingga dapat diketahui siapa pelaku dan akar masalahnya".

Konflik dalam konteks budaya juga terjadi di Indonesia. Menurut catatan Kompas konflik antarbudaya yang pernah terjadi seperti: "Tragedi Sampit, tragedi ini bermula dari konflik antara kelompok etnis Dayak dan Madura yang terjadi di Sampit, Kalimantan Tengah. Tempo mencatat konflik bermula pada 18 Februari 2001 saat empat anggota keluarga Madura, Matayo, Haris, Kama dan istrinya, tewas dibunuh. Warga Madura lantas mendatangi rumah milik suku Dayak bernama Timil yang dianggap telah menyembunyikan si pembunuh. Massa meminta agar Timil menyerahkan pelaku pembunuhan itu. Karena permintaan mereka tidak dituruti, massa marah dan membakar rumah. Insiden malam itu dapat dihentikan polisi. Sayang, pembakaran terus meluas ke rumah-rumah lainnya. Konflik-konflik lain banyak terjadi”.

Bila memperhatikan konflik yang terjadi baik di ranah agama maupun budaya, tidak menutup kemungkinan anak-anak terlibat. Konflik di tingkat anak-anak dimana anak menjadi pelaku atau korban, juga mengkhawatirkan. Komisi Perlindungan Anak Indonesia (KPAI) menyatakan tindakan bullying atau perundungan di dunia pendidikan menempati urutan keempat dalam kasus kekerasan anak yang terjadi di Indonesia. Berdasarkan data dari lembaga dunia Unicef. "Data Unicef tahun 2014 menyatakan delapan dari 10 anak mengalami bullying dan kasus bullying di Indonesia menempati urutan atau posisi keempat dalam kasus kekerasan anak," kata Komisioner Komisi Perlindungan Anak Indonesia (KPAI) Jasra Putra.

Lampung merupakan "Indonesia mini". Data sensus penduduk BPS tahun 2010 memperlihatkan bahwa jumlah penduduk Provinsi Lampung sebanyak 7608405 jiwa yang mencakup mereka yang bertempat tinggal di daerah perkotaan sebanyak 1955225 jiwa $(25,70$ persen) dan di daerah perdesaan sebanyak 5653180 jiwa (74,30 persen). Jumlah penduduk usia 7-12 tahun sebanyak 906853 jiwa, 13-15 tahun 456741 jiwa, 16-18 tahun 407060 jiwa dan 19-24 tahun 786140 jiwa. Sensus terhadap etnis atau suku bangsa adalah etnis Jawa 63,84\%, Lampung 13,51\%, Sunda 9,58\%, Banten 2,27\%, etnis asal Sumatera Selatan 5,47\%, etnis Bali 1,38\%, etnis Minangkabau 0,92\%, etnis Cina 0,53\%, etnis Bugis 0,28\%, etnis Batak 0,69\%, dan etnis lain seperti etnis asal Aceh, Jambi, Sumatera lainnya, Betawi, Papua, NTT, NTB, Kalimantan dan lain-lain sekitar 1,21\%.

Keberagaman yang ada di Lampung memunculkan konflik-fonflik antar suku. Pada tahun 2011, konflik antara suku Bali dengan Lampung yang terjadi di Lampung Selatan menelan korban 12 orang. 
Kasus konflik kekerasan di Lampung Selatan terulang kembali pada tahun 2012, dalam konflik tersebut, 14 korban meninggal dunia, belasan luka parah, dan 1.700 warga mengungsi dengan lama konflik mencapai 3 hari dari tanggal 27 sampai 29 Oktober 2012 (liputan6.com). Hasil penelitian Ariestha (2012) menyimpulkan bahwa konflik yang terjadi antara Etnik Bali (Balinuraga) dan Etnik Lampung (Agom) pada tanggal 27 sampai dengan 29 Oktober 2012 disebabkan oleh satu akar penyebab utama yaitu perilaku Etnik Bali (Balinuraga) dalam hidup bermasyarakat yang dianggap menyinggung perasaan dan tidak sesuai dengan adat istiadat etnik pribumi (Etnik Lampung).

Konflik yang terjadi di Indonesia mendorong pentingnya transformasi pendidikan yang mengutamakan pembentukan karakter bangsa. Hal inilah yang melandasi pemerintah memunculkan Gerakan Nasional Pendidikan Karakter Bangsa pada tahun 2010 dan sebagai kelanjutannya, pemerintah mencanangkan Gerakan Penguatan Pendidikan Karakter (PPK) pada tahun 2016. Gerakan PPK menempati kedudukan fundamental dan strategis pada saat pemerintah mencanangkan revolusi karakter bangsa sebagaimana tertuang dalam Nawacita 8 (Tim PPK Kemdikbud, 2016).

Seiring dan sejalan dengan usaha pemerintah, Prodi Pendidikan Guru Sekolah Dasar - Fakultas Pendidikan dan Bahasa Unika Atma Jaya memiliki mata kuliah pendidikan karakter dan pendidikan multikultural. Capaian akhir kedua mata kuliah ini saling terkait. Pada mata kuliah pendidikan karakter mahasiswa diharapkan mampu mendeskripsikan pendekatan dan strategi pelaksanaan pendidikan karakter di SD dengan mengkaji hakikat, tujuan, fungsi, media pendidikan karakter, dan karakter-karakter yang dapat dikembangkan siswa SD. Capaian mata kuliah pendidikan multikultural adalah mahasiswa dapat berperilaku sesuai dengan nilai-nilai yang dikembangkan dalam pendidikan multikultural dan mampu mentransformasikannya kepada peserta didiknya kelak. Nilai-nilai yang dikembangkan adalah, keterbukaan, menghargai perbedaan, menghargai kearifan lokal, dan asertif.

Sebagai pengampu mata kuliah pendidikan pendidikan karakter dan pendidikan multikultural, penulis juga melakukan serangkaian kegiatan yang berkaitan dengan penelitian dan pengabdian masyarakat. Pada mata kuliah pendidikan karakter, penulis melakukan observasi implementasi pendidikan karakter di SD. Observasi dilakukan di 30 Sekolah Dasar yang terletak di wilayah Jakarta, Bekasi, Bogor dan Tangerang pada tahun 2015. Observasi yang dilakukan mencakup dokumen pendukung, program pengembangan diri, proses pembelajaran, dan sarana prasarana. Berdasarkan hasil observasi diketahui sekolah telah mencantumkan karakter dalam visi, dan misi sekolah sebagai acuan penyelenggaraannya. Karakter utama siswa yang ingin dikembangkan oleh sekolah adalah religius. Program pengembangan diri yang dimiliki oleh sekolah mencakup kegiatan rutin dan kegiatan ekstrakurikuler. Kegiatan rutin yang dilaksanakan di sekolah, antara lain berdoa sebelum dan sesudah pelajaran, membersihkan lingkungan sekolah, dll. Kegiatan ekstrakurikuler yang ada di sekolah mencakup seni dan olahraga untuk menggali potensi, bakat, dan minat siswa. Contoh kegiatan ekstrakurikuler, antara lain Pramuka, paduan suara, marawis, futsal, dll.

Di dalam proses pembelajaran, guru mengintegrasikan pendidikan karakter dengan memperhatikan materi pelajaran yang sedang dipelajari. Integrasi pendidikan karakter dengan pembelajaran terlihat mulai dari proses merancang pembelajaran yakni dalam silabus dan RPP yang disusun oleh guru. Berdasarkan hasil observasi selama proses pembelajaran berlangsung, karakter yang perlu secara optimal dikembangkan adalah toleransi, demokratis, dan semangat kebangsaan.

Penelitian yang terkait dengan mata kuliah pendidikan multikultural, adalah penelitian dan pengembangan tentang model pendidikan multikultural di delapan SD Wilayah Jakarta, hasilnya menyatakan bahwa model pendidikan multikultural yang dikembangkan penting untuk keutuhan bangsa dan negara, model yang dikembangkan menarik bagi siswa dan guru, dan model ini dapat meningkatkan minat belajar siswa sehingga disarankan untuk disosialisasikan kepada guru-guru lain 
(Jurnal Teknologi Pendidikan: 2009). Penelitian dengan tema yang sama dilakukan di SMP, hasilnya menyatakan semua responden memandang pendidikan multikultural penting untuk diimplementasikan di sekolah melihat kondisi negeri kita yang sering konflik. Responden menyarankan agar model yang dikembangkan diberikan ke sekolah-sekolah lain karena sesuai dengan rencana pemerintah tentang membangun karakter bangsa (Jurnal Perkotaan: 2011).

Terakhir penelitian disertasi penulis menghasilkan model pembelajaran dan beberapa produk seperti bahan ajar Pendidikan Multikultural (2015) yang sudah teruji kelayakan karena dilakukan dengan sistematis mulai dari penelitian awal, pengembangan dan evaluasi. Hasil penelitian ini dapat diimplementasikan untuk mahasiswa calon guru pada program studi lainnya, guru yang belum mendapat pemahaman tentang pendidikan multikultural, dan siswa karena pendidikan multikultural adalah sebuah proses panjang yang berkesinambungan untuk membentuk karakter yang menghargai perbedaan sesuai dengan situasi NKRI yang Bhinneka.

Berdasarkan pembahasan di atas, penulis melakukan pengabdian masyarakat di Lampung, mengajak mahasiswa dengan tema "Mengembangkan Karakter Menghargai Perbedaan Melalui Pendidikan Multikultural". Mahasiswa yang terlibat adalah mahasiswa yang telah mengambil matakuliah Pendidikan Karakter dan Mata Kuliah Pendidikan Multikultural. Tujuan pengabdian masyarakat ini untuk menyadarkan warga sekolah betapa pentingkan mengembangkan karakter yang menghargai perbedaan.

\section{TINJAUAN PUSTAKA}

Dalam tulisan Dewantara (1933), dijelaskan bahwa karakter atau watak merupakan paduan daripada segala tabiat manusia yang bersifat tetap, sehingga menjadi tanda yang khusus untuk membedakan orang yang satu dengan yang lain. Dalam tulisannya pada tahun 1937, Dewantara mengungkapkan pula bahwa karakter atau budipekerti merupakan bersatunya gerak fikiran, perasaan, dan kehendak atau kemauan, yang lalu menimbulkan tenaga.

Lickona (2013) menjelaskan bahwa karakter memiliki tiga bagian yang sangat berhubungan yang meliputi pengetahuan moral, perasaan moral, dan perilaku moral. Karakter yang baik terdiri dari mengetahui hal yang baik, menginginkan hal yang baik, dan melakukan hal yang baik. Pembentukan karakter yang baik ini menuntut kebiasaan dalam cara berpikir, kebiasaan dalam hati, dan kebiasaan dalam tindakan. Ketiga hal ini membentuk kedewasaan moral.

Karakter tidak berkembang dalam ruang hampa, namun dalam lingkungan sosial. Oleh karena itu, dalam pengembangan karakter diperlukan intervensi dalam bentuk upaya-upaya yang salah satunya merupakan proses pendidikan. Samani dan Hariyanto (2013) mengungkapkan bahwa pendidikan karakter merupakan proses pemberian tuntunan kepada peserta didik untuk menjadi manusia seutuhnya yang berkarakter dalam dimensi hati, pikir, raga, serta rasa dan karsa.

Dalam Gerakan Penguatan Pendidikan Karakter (PPK), terdapat lima nilai utama karakter bangsa yang menjadi prioritas untuk dikembangkan, yaitu religious, nasionalis, mandiri, gotong-royong, dan integritas. Gerakan PPK ini dapat dilaksanakan oleh sekolah dengan berbasis kelas, budaya sekolah, dan masyarakat atau komunitas. (Tim PPK Kemdikbud, 2016).

Pendidikan multikultural merupakan pengakuan nilai-nilai individu dan pengembangan potensi individu sehingga individu mampu menghargai budaya etnis mereka sendiri serta menghargai kebudayaan kelompok etnis lainnya di seluruh dunia (Liu \& Lin: 2011). Dalam konteks Indonesia, Tilaar (2004) mengatakan pendidikan multikultural menumbuhkan sikap toleran bagi warga masyarakat agar mengakui pluralisme dan merupakan upaya untuk mengurangi gesekan-gesekan atau 
ketegangan-ketegangan yang diakibatkan oleh perbedaan-perbedaan dalam masyarakat. Tilaar juga menekankan bahwa pendidikan multikultural merupakan upaya mereduksi berbagai jenis prasangka sosial yang secara potensial hidup dalam masyarakat pluralis

Jelas terlihat bahwa pendidikan multikultural merupakan upaya agar semua orang mampu menghargai orang lain yang berbeda dengannya. Pendekatan pembelajaran dalam mata kuliah pendidikan multikultural tentu pendekatan yang berpusat kepada mahasiswa agar mahasiswa berinteraksi satu sama lain. Beberapa metode pembelajaran yang digunakan adalah diskusi, mahasiswa membahas teori secara mendalam. Metode bermain peran digunakan untuk berlatih meningkatkan sikap asertif, mendiskusikan video kearifan lokal, merancang dan mengimplementasikan upaya mengembangkan nilai-nilai menghargai perbedaan.

Untuk mengimplementasikan pendidikan multikultural di tingkat sekolah dasar, dibutuhkan seorang guru yang hebat yaitu guru yang menghargai siswanya, yang mendorong siswa untuk mencapai prestasi tertinggi, yang membuat pembelajaran menarik, dan yang benar-benar peduli tentang kepentingan terbaik siswa mereka. Guru yang hebat adalah guru yang menutup kesenjangan prestasi peserta didik - terlepas dia dari ras, etnis, kelas sosial, ekonomi, bahasa, atau lokasi geografis dengan pembelajaran yang berkualitas tinggi yang akan mendorong dan membantu peserta didik untuk mencapai prestasinya. Artinya guru harus peduli terhadap kualitas pendidikan anak-anaknya, terlepas dari latar belakang mereka. Menurut DomNwachukwu, peran guru bukan sebagai polisi budaya, tetapi seorang pendidik yang dapat berperan sebagai teman bagi siswanya yang berada di perjalanan menuju arah pengembangan diri dan realisasi diri. Agar bisa lebih efektif mendidik siswa dari berbagai latar belakang, guru pertama-tama datang harus berdamai dengan identitas budaya siswanya, dan langkah berikutnya menegaskan sisi kemanusiaan dalam kelasnya, serta menegaskan identitas budaya masing-masing. Pendekatan-pendekatan pembelajaran inilah yang akan dibahas dalam pengabdian masyarakat.

\section{METODOLOGI}

Pengabdian masyarakat ini dilakukan dengan 3 tahap, pertama analisis kebutuhan, kedua merancang kegiatan, ketiga pelaksanaan dan evaluasi. Analisis kebutuhan dilakukan dengan kunjungan ke SD Fransiskus 2 Lampung untuk melihat dan menganalisis kebutuhan masyarakat sekolah sesuai dengan kompetensi penulis. Wawancara dilakukan dengan Kepala Sekolah dengan perwakilan seorang guru. Penulis menceritakan latar belakang pengabdian masyarakat yang akan dilakukan yaitu pendidikan karakter yang terintegrasi dengan pendidikan multikultural. Pemilihan topik tersebut, selain sesuai dengan kompetensi penulis, topik ini juga sangat terkait dengan penelitian-penelitian yang sudah dilakukan. Lampung dipilih karena beberapa kali terjadi konflik antarsuku terjadi di sana. Pada tahap ini terungkap bahwa perlu kegiatan untuk menyadarkan warga sekolah bahwa meningkatkan karakter yang menghargai keberagaman dapat dilakukan dengan pendekatan pendidikan multikultural. Ada dua kegiatan yang dibutuhkan, pertama sosialisasi kepada guru dan kedua memberikan pengalaman belajar kepada siswa tentang mengembangkan karakter melalui pendidikan multikultural.

Berdasarkan hasil tahap pertama, tahap berikutnya adalah merancang kegiatan. Penulis membuat makalah untuk seminar guru. Materi yang disiapkan dalam bentuk teori dan implementasi di kelas. Rancangan kegiatan seminar diawali dengan memberi pengalaman belajar kepada guru sebagai contoh implementasi pendidikan karakter dan mutikultural. Untuk kegiatan pembelajaran yang diberikan oleh mahasiswa kepada siswa, Penulis menyiapkan 84 mahasiswa untuk membuat rancangan kegiatan di kelas yang bertujuan mengembangkan karakter yang menghargai perbedaan. Semua mahasiswa juga mempersiapkan media pembelajaran yang akan mereka gunakan. Pada dasarnya mahasiswa sudah mendapatkannya pada mata kuliah terkait. Mahasiswa yang terlibat 
diminta mengkonsultasikan rancangan kegiatannya kepada dosen lain.

Tahap ketiga pelaksanaan, seminar interaktif diselenggarakan dengan 50 peserta yang terdiri dari guru dan dosen. Pelatihan kepada masyarakat sekolah, yaitu guru dan 480 siswa yang terdiri dari kelas 1 sampai kelas V, terbagi dalam 16 kelas, masing-masing kelas ada sekitar 30 siswa. Mahasiswa yang terlibat dalam pelatihan 84 orang.

\section{HASIL ANALISIS}

Hasil analisis kebutuhan terlihat bahwa topik ini sangat disukai karena sangat terkait dengan situasi Lampung dimana telah terjadi beberapa kali konflik antarsuku yang menelan korban. Suku yang terlibat dalam konflik adalah suku Bali dan penduduk asli Lampung. Karena topik ini merupakan hal yang baru bagi sekolah, kepala sekolah meminta agar dilakukan seminar dengan tanya jawab yang intensif sehingga dapat menyadarkan guru-guru betapa pentingnya mengembangkan karakter yang menghargai perbedaan.

Seminar untuk guru-guru dengan topik Membangun Karakter Anak Melalui Pendekatan Multikultural dilakukan dengan pembehasan dari sisi teori dan implementasi. Materi pendidikan karakter adalah hakikat pendidikan karakter, pentingnya karakter bagi suatu bangsa, ruang lingkup pendidikan karakter, dan strategi pendidikan karakter di sekolah.

Materi pendidikan multikultural yang dibahas adalah: keragaman Indonesia; gambaran berbagai konflik; pendekatan multikultural salah satu alternatif yang dapat mengembangkan karakter yang menghargai perbedaan pada peserta didik; sikap yang dikembangkan yaitu mengenal identitas diri, penghargaan terhadap diri sendiri, keterbukaan terhadap orang lain, menghargai perbedaan, mengelola konflik, berpikir kritis, bersikap asertif, dan menghargai kearifan lokal; sikap yang perlu dihindari yaitu prasangka dan stereotipe; metode pembelajaran yang dapat digunakan seperti menonton video tentang budaya Indonesia, diskusi kelompok, presentasi di depan kelas, dan permainan di luar kelas. Penekanan metode pembelajaran adalah kegiatan yang terpusat kepada siswa. Kegiatan pembelajaran yang dirancang harus sangat menarik, menyenangkan dan efektif.

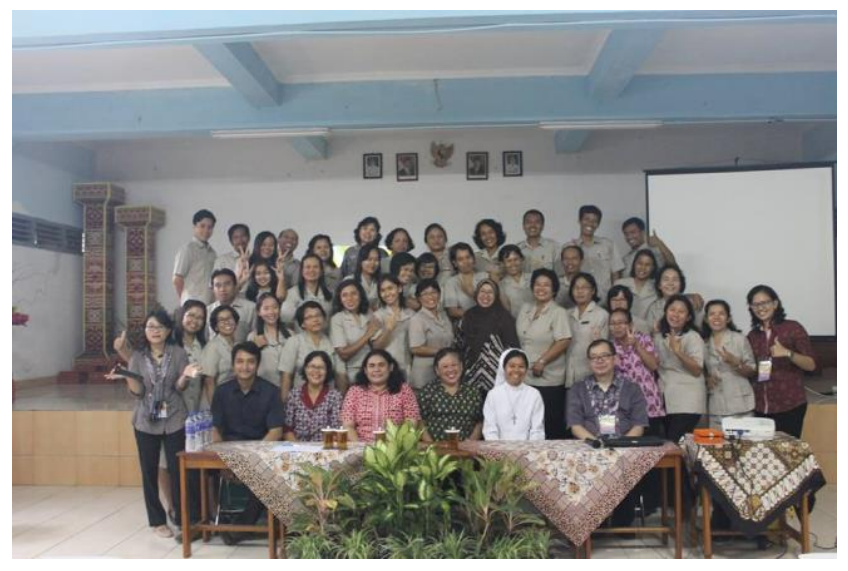

Gambar 1. Penulis bersama dengan para guru SD Fransiskus 2 Lampung

Pada kegiatan seminar guru-guru diberi pengalaman belajar dengan permainan "Oper Koran". Beberapa orang guru maju ke depan, berbaris dengan komposisi, laki-laki perempuan, tinggi pendek. Koren dioper dari guru yang paling depan dengan menggunakan bahu sampai kepada guru yang paling belakang. Nilai yang dikembangkan dengan permainan ini adalah menghargai keterbatasan 
teman, menggalang kepedulian dan empati. Setelah mengalami, teori dan pendidikan karakter dan pendidikan multicultural dibahas dengan tanya jawab.

Sebagai penutup dikatakan, "bila kita para guru dapat mengembangkan karakter anak bangsa yang menghargai perbedaan sesuai semboyan negara Bhinneka Tunggal Ika maka konflik desktruktif akan berkurang".

Kegiatan mengajar oleh mahasiswa dengan mengimplementasikan rancangan yang sudah disiapkan di Jakarta. Kegiatan di dalam kelas dilakukan dengan team teaching mulai kelas I sampai kelas V dengan tema yang sama yaitu mengembangkan karakter anak melalui pendidikan multikultural. Ada 480 siswa yang terbagi dalam 16 kelas, masing-masing kelas ada sekitar 30 siswa. Kegiatan pembelajaran yang dibuat sangat bervariasi begitu juga dengan nilai-nilai yang dikembangkan.

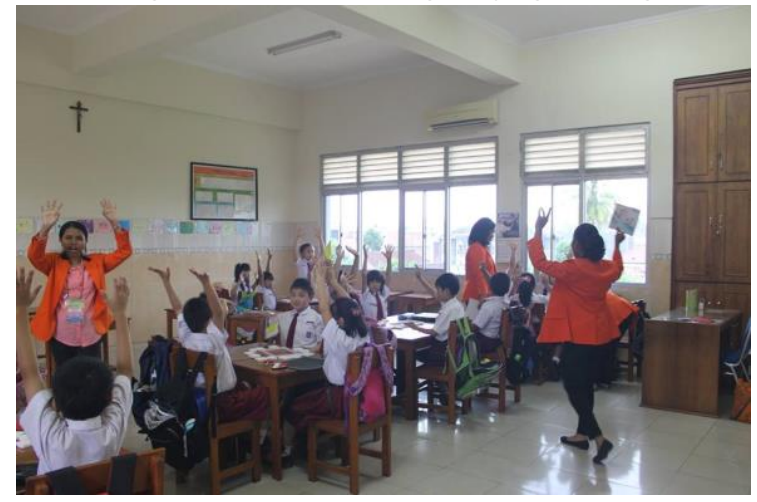

Gambar 2. Mahasiswa Prodi PGSD bersama dengan siswa SD Fransiskus 2 Lampung

Nilai-nilai yang dikembangkan yaitu; kerjasama, menghargai perbedaan, hidup rukun, gotong royong, menghargai setiap profesi, cinta tanah air, dan kreatif. Materi yang diberikan tentang rumah adat, pakaian adat, senjata tradisional, profesi, lagu tradisional, panca sila dan perbedaan agama. Metode yang digunakan: ceramah, diskusi, membaca cerita, main puzzle dengan kelompok, bernyanyi, mendongeng, membuat pohon cita-cita, pesan berantai, dan nonton video.

\section{DISKUSI}

Pelaksanaan pengabdian masyarakat ini dilakukan dalam rangkaian Tri Darma Perguruan Tinggi, dimana ada keterkaitan antara pengajaran di kelas, penelitian dan pengabdian masyarakat. Penulis mengampu mata kuliah pendidikan karakter dan pendidikan multikultural. Dari diskusi panjang dan kajian-kajian yang penulis lakukan bersama maka terlihat ada keterkaitan antara kedua mata kuliah tersebut.

Pemilihan topik mengembangkan karakter menghargai perbedaan dipandang sangat penting oleh Kepala Sekolah dan guru-guru yang ikut seminar. Topik seminar sangat bermakna karena menyadarkan guru-guru bahwa mengembangkan karakter menghargai perbedaan dapat dilakukan dalam kegiatan pembelajaran. Pemilihan topik yang diawali dengan analisis kebutuhan dan kegiatan seminar yang bervariasi antara ceramah, permainan dan diskusi sangat efektif dalam pencapaian tujuan seminar karena guru-guru punya gambaran bagaimana melaksanakannya di kelas. Kegiatan pengabdian masyarakat ini sesuai dengan pendapat Bank (2010), yang menekankan bahwa pendidikan multikultural itu merupakan gagasan atau konsep, sebuah gerakan reformasi pendidikan, dan proses. Sebagai sebuah gagasan, pendidikan multikultural menggabungkan semua peserta didik yang berasal dari jenis kelamin, kelas sosial, etnis, ras, atau budaya agar memiliki kesempatan yang sama untuk belajar di sekolah sebagai sistem sosial. Pendidikan multikultural juga merupakan 
gerakan reformasi yang sedang mencoba untuk mengubah sekolah dan lembaga pendidikan lainnya agar mau menerima siswa dari semua kelas sosial, jenis kelamin, ras, bahasa, dan kelompok budaya sehingga akan memiliki kesempatan yang sama untuk belajar. Kenyataannya masih ada sekolah yang tidak memberi kesempatan kepada siswa yang mempunyai karakter yang berbeda. Pendidikan multikultural harus dipandang sebagai suatu proses yang berkelanjutan, bukan sebagai sesuatu yang kita lakukan sekarang, dengan demikian proses berkelanjutan merupakan pemecahan masalah yang merupakan target dari reformasi pendidikan multikultural yang menghargai semua perbedaan.

Mahasiswa yang sudah dipersiapkan untuk kegiatan di kelas, dengan menggunakan metode dan media yang bervariasi sangat efektif dalam pencapaian pengabdian masyarakat ini. Siswa SD Fransiskus sangat terkesan dan sangat menyukai kegiatan pembelajaran. Pembelajaran yang terpusat kepada siswa dan mengaktifkan siswa dalam kelompok sehingga ada interaksi sesama mereka. Pendekatan seperti ini menciptakan dialog sehingga memunculkan sikap yang menghargai perbedaan. Disinilah peran guru dalam memfasilitasi kegiatan pembelajaran sesuai dengan pendekatan cooperative learning yang sudah dibuktikan melalui penelitian. Pendekatan pembelajaran kooperatif untuk meningkatkan hubungan antar kelompok. Oleh karena itu guru harus mendesain pembelajaran yang melibatkan semua peserta didik (Stephan: 2004).

Kegiatan pengabdian masyarakat yang melibatkan mahasiswa akan berdampak positif pada mahasiswa terutama 1) Melatih kepedulian mahasiswa sebagai calon pendidik terhadap sesama 2) Mengaplikasikan teori yang mereka pelajari dari mata kuliah pendidikan karakter dan pendidikan multikultural.

\section{KESIMPULAN.}

Bagi sekolah, kegiatan ini sangat bermanfaat bagi guru dan siswa. Guru-guru menambah pengetahuan baru dan merasakan manfaat pentingnya materi yang diberikan khususnya dengan melihat situasi wilayah mereka yang beberapa tahun terakhir ini terjadi konflik antarbudaya. Siswa-siswi juga merasakan bahwa kehadiran mahasiswa sangat menyenangkan bagi mereka. Selain itu, karena kegiatan ini baru pertama kali dilaksanakan di sekolah, mereka berharap kegiatan ini dapat diperpanjang waktunya.

Pengabdian masyarakat ini juga sangat membantu mahasiswa untuk mengimplementasikan ilmu yang sudah di dapat dan mengasa sikap peduli siswanya.

\section{DAFTAR PUSTAKA}

Affan, H. (21 Juli 2015). Polisi dituntut segera menuntaskan insiden Tolikara. Diambil pada tanggal 8 Oktober 2018, dari https://www.bbc.com/indonesia/berita_indonesia/2015/07/150720_indonesia_update_tolikar a.

Ariesta, B. (2012). Akar konflik kerusuhan antar etnik di Lampung Selatan. Journal of Social and Industrial Psychology. Nomor 01/II.

Badan Pusat Statistik. (Tanpa Tahun). Mengulik data suku di Indonesia. Diambil pada tanggal 25 September 2018, dari https://www.bps.go.id/news/2015/11/18/127/mengulik-data-suku-diindonesia.html

Badan Pusat Statistik. (Tanpa Tahun).Kewarganegaraan, suku bangsa, agama dan bahasa sehari-hari penduduk Indonesia. Diambil pada tanggal 8 September 2018, dari http//sp2010.bps.go.id/files/ebook/kewarganegaraan.

Banks, J.A. (2010). Multicultural education: Characteristics and goals, dalam Banks, James A and Cherry A. Mcgee., Eds, Multicultural Education Issues And Perspectives. (Ed.7). New York: John Wiley \& Sons. 
Dahlan, M. (2013). Paradigma ushul fiqh multikultural gus dur. Bengkulu: Kaukaba.

Dewantara, K.H. (1933). Hal watak: Watak ditinjau secara sintetis dan analitis. Yogyakarta: Majelisluhur Persatuan Taman Siswa.

Dewantara, K.H. (1937). Dasar-dasar Pendidikan. Yogyakarta: Majelisluhur Persatuan Taman Siswa.

Dewantara, K.H. (1937). Dasar-dasar Pendidikan. Yogyakarta: Majelisluhur Persatuan Taman Siswa.

DomNwachukwu, C. S. (2010). An introduction to multicultural education from theory to practice. Lanham • New York • Toronto • Plymouth: Rowman \& Littlefield Publishers.

Fisher, S, et al. (2000). Mengelola konflik [Responding to conflict] (S.N. Kartikasari, dkk, penerj.) Jakarta: The British Council.

Hendrian, D. (27 Juli 2018). KPAI: Perundungan urutan keempat kasus kekerasan anak. Diambil pada tanggal 10 Oktober 2018, dari http://www.kpai.go.id/berita/kpai-perundungan-urutan-keempatkasus-kekerasan-anak.

Kristanti, E.Y. (23 Desember 2012). LSI: Ini 5 Kasus Kekerasan Paling Mengerikan di Indonesia. Diambil pada tanggal 10 Oktober 2018, dari https://www.liputan6.com/news/read/473537/lsiini-5-kasus-kekerasan-paling-mengerikan-di-indonesia

Lickona, T. (2013). Mendidik untuk membentuk karakter [Educating for character] (Juma Abdu Wamaungo, penerj.). Jakarta: Bumi Aksara

Liu, M \& Lin, T. (2011). The Development of Multicultural Education in Taiwan Overview and Reflection, dalam Grant and Portera, eds, Intercultural and Multicultural Education Enhancing Global Interconnectedness. New York: Routledge.

Samani, M \& Hariyanto. (2013). Konsep dan model pendidikan karakter. Bandung: Remaja Rosdakarya.

Stephan, W. G \& Vogt, W. P. (2004). “Introduction: Education's Influence on Beliefs, Attitudes, Values, amd Behaviors" dalam Education Programs for Improving Intergroup Relations Theory, Research, and Practice. New York and London: Teachers College Press.

Suparman, A. (2014). Desain instruksional modern: Panduan para pengajar dan inovator pendidikan. Jakarta: Penerbit Erlangga.

Tempo.co. (21 Mei 2015). Konflik yang dipicu keberagaman budaya Indonesia. Diambil pada tanggal 10 Oktober 2018 dari https:/nasional.tempo.co/read/668047/konflik-yang-dipicukeberagaman-budaya-indonesia/full\&view $=$ ok.

Tilaar, H.A.R. (2004). Multikulturalisme tantangan-tantangan global masa depan dalam transformasi pendidikan nasional. Jakarta: Grasindo.

Tim PPK Kemdikbud. (2016). Konsep dan pedoman penguatan pendidikan karakter tingkat sekolah dasar dan sekolah menengah pertama. Jakarta: Kemdikbud.

Wiwoho, B. (2018). Kelompok intoleran ancam kerukunan umat beragama. Diambil pada tanggal 30 September 2018 dari https://www.cnnindonesia.com/nasional/20180212070430-20275505/kelompok-intoleran-ancam-kerukunan-umat-beragama. 